\title{
Thermal and spectroscopic study to investigate $p$-aminobenzoic acid, sodium $p$-aminobenzoate and its compounds with some lighter trivalent lanthanides
}

\author{
J.A. Teixeira ${ }^{a}$, W.D.G. Nunes ${ }^{a}$, T.A.D. Colman ${ }^{a}$, A.L.C.S do Nascimento ${ }^{a}$, F.J. Caires ${ }^{b}$, \\ F.X. Campos ${ }^{\mathrm{a}, \mathrm{c}}$, D.A. Gálico ${ }^{\mathrm{d}}$, M. Ionashiro ${ }^{\mathrm{a}, *}$ \\ a Instituto de Química, UNESP-Universidade Estadual Paulista, Campus Araraquara, Departamento de Química Analítica, Araraquara 14801-970, SP, Brazil \\ ${ }^{\mathrm{b}}$ Faculdade de Ciências, UNESP-Universidade Estadual Paulista, Campus Bauru, Departamento de Química, Bauru 17033-260, SP, Brazil \\ ${ }^{\mathrm{c}}$ Instituto Federal de Educação, Ciência e Tecnologia de Mato Grosso, Primavera do Leste 78850-000, MT, Brazil \\ d Instituto de Química, UNICAMP-Universidade Estadual de Campinas, Campinas 13083-970, SP, Brazil
}

\section{A R T I C L E I N F O}

\section{Article history:}

Received 14 August 2015

Received in revised form

13 November 2015

Accepted 28 November 2015

Available online 17 December 2015

\section{Keywords:}

Lighter trivalent lanthanides

p-Aminobenzoates

Thermal behavior

Spectroscopy

Evolved gases

\begin{abstract}
A B S T R A C T
The characterization, thermal stability and thermal decomposition of some lighter trivalent lanthanide $p$-aminobenzoates, $\mathrm{Ln}\left(\mathrm{C}_{7} \mathrm{H}_{6} \mathrm{NO}_{2}\right)_{3} \cdot \mathrm{H}_{2} \mathrm{O}(\mathrm{Ln}=\mathrm{La}, \mathrm{Ce}, \mathrm{Pr}, \mathrm{Nd}, \mathrm{Sm})$, as well as the thermal behavior and spectroscopic study of $p$-aminobenzoic acid $\mathrm{C}_{7} \mathrm{H}_{7} \mathrm{NO}_{2}$ and its sodium salt were investigated. The following methods were utilized: simultaneous thermogravimetry and differential thermal analysis (TG-DTA) in dynamic dry air and nitrogen atmospheres; differential scanning calorimetry (DSC); middle (MIR) and near (NIR) infrared region spectroscopy; evolved gas analysis (EGA); elemental analysis; complexometry; X-ray diffraction (XRD); and diffuse reflectance spectroscopy (DR) in the ultraviolet and visible regions. All the compounds were obtained monohydrated and the thermal decomposition occurred in two, three or four steps in an air atmosphere, and three or four steps in $\mathrm{N}_{2}$ atmosphere. In both atmospheres (air and $\mathrm{N}_{2}$ ) the final residues were $\mathrm{CeO}_{2}, \mathrm{Pr}_{6} \mathrm{O}_{11}, \mathrm{Ln}_{2} \mathrm{O}_{3}(\mathrm{Ln}=\mathrm{La}, \mathrm{Nd}, \mathrm{Sm})$. The results also provided information concerning the coordination mode and thermal behavior, as well as the identification of the gaseous products which evolved during the thermal decomposition of these compounds. The DR and NIR spectra provided information about the ligand absorption bands and the $f-f$ transitions of the $\mathrm{Nd}^{3+}, \operatorname{Pr}^{3+}$ and $\mathrm{Sm}^{3+}$ ions.
\end{abstract}

(c) 2015 Elsevier B.V. All rights reserved.

\section{Introduction}

p-Aminobenzoic acid (H-pABA), whose molecular formula is $\mathrm{C}_{7} \mathrm{H}_{7} \mathrm{NO}_{2}$ and which has a molar mass of $137.14 \mathrm{~g} \mathrm{~mol}^{-1}$, is a cyclic amino acid obtained as a crystalline powder or white/whiteyellowish needles. It is also known as vitamin $B_{10}$. Although the human organism does not synthesize it, H-pABA is a component which is present in foods. It is produced by essential symbiotic bacteria and is metabolized constantly in the human body [1-3]. In lower concentrations it is a precursor of folic acid, and in high concentrations its role has been studied in the inhibition of various bacteria and viruses, showing anticoagulant, antioxidant and immunomodulatory properties. It is an one active ingredient in formulations against ultra-violet radiation [2,3]. In vivo and in vitro assays have demonstrated the efficacy of $\mathrm{H}$-pABA in the treatment

\footnotetext{
* Corresponding author. Tel.: +55 1633019617.

E-mail address: massaoi@yahoo.com.br (M. Ionashiro).
}

of ocular viral herpes; its efficacy is primarily related to its capacity to induce the synthesis of endogenous interferon in the human body $[2,3]$.

Several studies of the coordination compounds formed by metallic ions and organic substances, such as pharmaceuticals and benzoic acid derivatives, have been reported [4-11]. These types of compounds have a great structural variety and also the ability to be used in new technological applications. Such compounds present great potential to be employed in the pharmaceutical area as biomarkers and new drugs, as industrial lasers and luminescent materials and in catalysis, among other applications [8-13].

The literature contains reports of the thermal decomposition and the spectroscopic study of $m$-aminobenzoic acid coordination compounds with lanthanide ions and yttrium. One such study indicates the formation of compounds presenting 4 to 6 water molecules, with coordination occurring between the amino and carboxylate groups, to form a polymeric structure [14]. The coordination compounds formed between $\mathrm{Eu}(\mathrm{III})$ and $\mathrm{Tb}$ (III) ions with aminobenzoates presented different luminescent properties due to 
the strong electron donor effect of the $\mathrm{NH}_{2}$ group in the ortho, meta and para positions of the benzene ring [15]. A fluorescence lifetime of $0.58 \mathrm{~ms}$ and emission quantum yield of 0.67 were obtained for the $\left[\mathrm{Tb}(\mathrm{pABA})_{3}\left(\mathrm{H}_{2} \mathrm{O}\right)_{2}\right] \cdot 2 \mathrm{H}_{2} \mathrm{O}$ complex [16]. Single crystals were obtained by the association of H-pABA and lanthanides, except $\mathrm{Gd}(\mathrm{III}), \mathrm{Nd}(\mathrm{III})$ and $\mathrm{Tm}(\mathrm{III})$, forming polymeric (La, Ce, Pr, Sm, Eu, $\mathrm{Tb}$, Dy and $\mathrm{Er}$ ) and binuclear (Tb, Ho, Yb, Lu and Y) structures depending on the $\mathrm{pH}$ of the prepared solutions. The structures were determined by XRD, elemental analysis, infrared spectroscopy and thermogravimetric analysis [17].

Although many studies in the literature describe the synthesis and characterization of coordination compounds formed between $p$-aminobenzoic acid and lanthanide ions, there is no systematic study investigating the thermal behavior of these materials in the solid state. The present study describes the synthesis, characterization and thermal behavior of $p$-aminobenzoic acid, sodium $p$-aminobenzoate and some lighter trivalent lanthanide $p$-aminobenzoates in the solid-state. The characterization was performed using thermoanalytical techniques (TG-DTA, DSC, EGA) and complementary techniques (complexometry, elemental analysis, $\mathrm{X}$-ray diffraction (XRD), diffuse reflectance (DR), mid-infrared spectroscopy (MID) and near-infrared region spectroscopy (NIR)).

\section{Experimental}

\subsection{Synthesis}

The $p$-aminobenzoic acid ( $\mathrm{H}-\mathrm{pABA}) \mathrm{C}_{7} \mathrm{H}_{7} \mathrm{NO}_{2}$ used in this study was of $99 \%$ purity and was obtained from Sigma; it was used as received. Aqueous solution of sodium $p$-aminobenzoate (Na-pABA) $0.1 \mathrm{~mol} \mathrm{~L}^{-1}$ was prepared by neutralization of aqueous suspension of $\mathrm{H}$-pABA with sodium hydroxide solution $0.1 \mathrm{~mol} \mathrm{~L}^{-1}$.

Lanthanide chloride solutions were prepared from the corresponding metal oxides (except for cerium) by treatment with concentrated hydrochloric acid, following the procedure described in the literature [18].

The solid-state compounds were obtained by slowly adding (with stirring) $160.0 \mathrm{~mL}$ of the ligand $0.1 \mathrm{~mol} \mathrm{~L}^{-1}$ heated up to near ebullition to $50.0 \mathrm{~mL}$ of the respective metal ions solutions $0.1 \mathrm{~mol} \mathrm{~L}^{-1}$, which were also heated. The solutions with the precipitates were maintained at ambient temperature, filtered and washed with ethanol (to eliminate the possible presence of $\mathrm{H}$-pABA) and distilled water until the elimination of chloride and nitrate ions (qualitative test with $\mathrm{AgNO}_{3} / \mathrm{HNO}_{3}$ solution for chloride ions or diphenylamine $/ \mathrm{H}_{2} \mathrm{SO}_{4}$ solution for nitrate ions). The solid was then dried at $50^{\circ} \mathrm{C}$ in a forced circulation air oven for $12 \mathrm{~h}$ and kept in a desiccator over anhydrous calcium chloride.

\subsection{Experimental equipment and conditions}

In the solid-state, lanthanide ions, hydration water and ligand contents were determined from TG curves. The metal ions were also determined by complexometry with standard EDTA solutions after igniting the compounds to the respective oxides and their dissolution in hydrochloric acid solution $[19,20]$.

Carbon, hydrogen and nitrogen contents were determined by microanalytical procedures, with a CHN Elemental Analyzer from Perkin Elmer, model 2400.

X-ray powder patterns were obtained by using a Siemens D$5000 \mathrm{X}$-Ray Diffractometer employing $\mathrm{CuK \alpha}$ radiation $(\lambda=1.541 \AA)$ and setting of $40 \mathrm{kV}$ and $20 \mathrm{~mA}$.

Mid-infrared spectra (MIR) for H-pABA, Na-pABA and for its metal-ion compounds were run on a Nicolet iS 10 FTIR spectrophotometer, using ATR accessory with Ge window. The MIR spectra were recorded in the region of $4000-600 \mathrm{~cm}^{-1}$ with 32 scans per spectrum at the resolution of $4 \mathrm{~cm}^{-1}$.
Near infrared spectra (NIR) were collected using a Thermo Scientific Antaris II spectrophotometer by reflectance, within the $1000-2500 \mathrm{~nm}$ range.

Diffuse reflectance (DR) spectra were acquired using a Varian Cary 5000 spectrophotometer within the $200-1000 \mathrm{~nm}$ range with spectral resolution of $0.5 \mathrm{~nm}$.

Simultaneous TG-DTA and DSC curves were obtained with two thermal analysis systems, model SDT 2960 and Q10, both from TA Instruments. The purge gas was an air or nitrogen flow of $100 \mathrm{~mL} \mathrm{~min}^{-1}$. A heating rate of $10^{\circ} \mathrm{C} \mathrm{min}^{-1}$ was adopted, with samples weighing about $4 \mathrm{mg}$ for TG-DTA and $2 \mathrm{mg}$ for DSC. Alumina and aluminium crucibles, the latter with perforated cover, were used for recording the TG-DTA and DSC curves, respectively.

The images were obtained on equipment Mettler-Toledo DSC 1 stare system coupled to OLYMPUS digital camera; model SC 30 which incorporates a 3.3 megapixel CMOS sensor, optical sub-assembly mechanic Navitar 1-6232D with $6.5 \times$ zoom. The experimental conditions were similar to those used to obtain the DSC curve.

The measurements of evolved gaseous analysis (EGA) were carried out using a TG-DSC 1 Mettler Toledo coupled to a FTIR spectrophotometer Nicolet with gas cell and DTGS KBr detector. The furnace and heated gas cell $\left(250^{\circ} \mathrm{C}\right)$ were coupled through a heated $\left(225^{\circ} \mathrm{C}\right) 120 \mathrm{~cm}$ stainless steel line transform with diameter of $3.0 \mathrm{~mm}$, both purged with dry air and nitrogen $\left(50 \mathrm{~mL} \mathrm{~min}^{-1}\right)$. The MIR spectra were recorded with 16 scans per spectrum at a resolution of $4 \mathrm{~cm}^{-1}$.

\section{Results and discussion}

\subsection{Thermal analysis}

\subsection{1. $H-p A B A$}

Simultaneous TG-DTA curves in dynamic dry air and $\mathrm{N}_{2}$ atmospheres of H-pABA are shown in Fig. $1 a$ (air) and $b\left(\mathrm{~N}_{2}\right)$. In both atmospheres, these curves showed total mass losses in two steps between $120-550{ }^{\circ} \mathrm{C}$ (air) and $120-510^{\circ} \mathrm{C}\left(\mathrm{N}_{2}\right)$ with losses of 95.91 and $4.09 \%$ (air) or 96.05 and $3.95 \%\left(\mathrm{~N}_{2}\right)$. In both atmospheres the beginning of mass loss that occurred slowly between 120 and $180^{\circ} \mathrm{C}$, with loss of $4.75 \%$ (air) and $4.69 \%\left(\mathrm{~N}_{2}\right)$, and without any thermal event on the DTA curve, was attributed to the partial sublimation of the compound, which was confirmed by visual inspection of the sample heated on a heating plate. The endothermic peaks (air, $\mathrm{N}_{2}$ ) at 188 and $240{ }^{\circ} \mathrm{C}$ observed in the DTA curves were attributed to the melting and partial evaporation of the compound, respectively. The samples were heated in a glass tube up to 188 and $240{ }^{\circ} \mathrm{C}$ and, as indicated by the TG-DTA curves, melting followed by evaporation of the compound was observed. The infrared spectra of the recrystallized and condensed product from melting and evaporation, respectively, were the same as the original sample, in disagreement with Ref. [21].

In air atmosphere, the exothermic peak at $530^{\circ} \mathrm{C}$ was attributed to the oxidation of the carbonaceous residue. For the $\mathrm{N}_{2}$ atmosphere, the small endothermic event between 440 and $500^{\circ} \mathrm{C}$ was attributed to pyrolysis of the carbonaceous residue. The formation of carbonaceous residue after the melting and partial evaporation step was confirmed, by heating the samples up to $290^{\circ} \mathrm{C}$, as indicated by the TG-DTA curves.

The infrared spectra of the gases which evolved during the thermal decomposition of the H-pABA in both the atmospheres are shown in Fig. 1c and d. The IR spectra obtained were compared with library FTIR spectra contained in the software of the spectrometer, and also literature data. In both atmospheres, the FTIR spectrum obtained at $242{ }^{\circ} \mathrm{C}$ (Fig. 1c) showed bands at $2356 \mathrm{~cm}^{-1}\left(v_{\mathrm{COO}}\right)$, $668 \mathrm{~cm}^{-1}\left(\delta_{\mathrm{COO}}\right), 3045 \mathrm{~cm}^{-1}\left(v_{\mathrm{C}-\mathrm{H}_{\mathrm{ar}}}\right), 1622 / 1510 \mathrm{~cm}^{-1}\left(v_{\mathrm{C}=\mathrm{C}_{\mathrm{ar}}}\right)$, $1273 \mathrm{~cm}^{-1}\left(\nu_{\mathrm{C}-\mathrm{N}_{\mathrm{amine}}}\right), 1173-1085 \mathrm{~cm}^{-1}\left(\delta_{\mathrm{CCC}_{\mathrm{ar}}}\right), 875 \mathrm{~cm}^{-1}\left(\beta_{\mathrm{C}-\mathrm{H}_{\mathrm{ar}}}\right)$ 


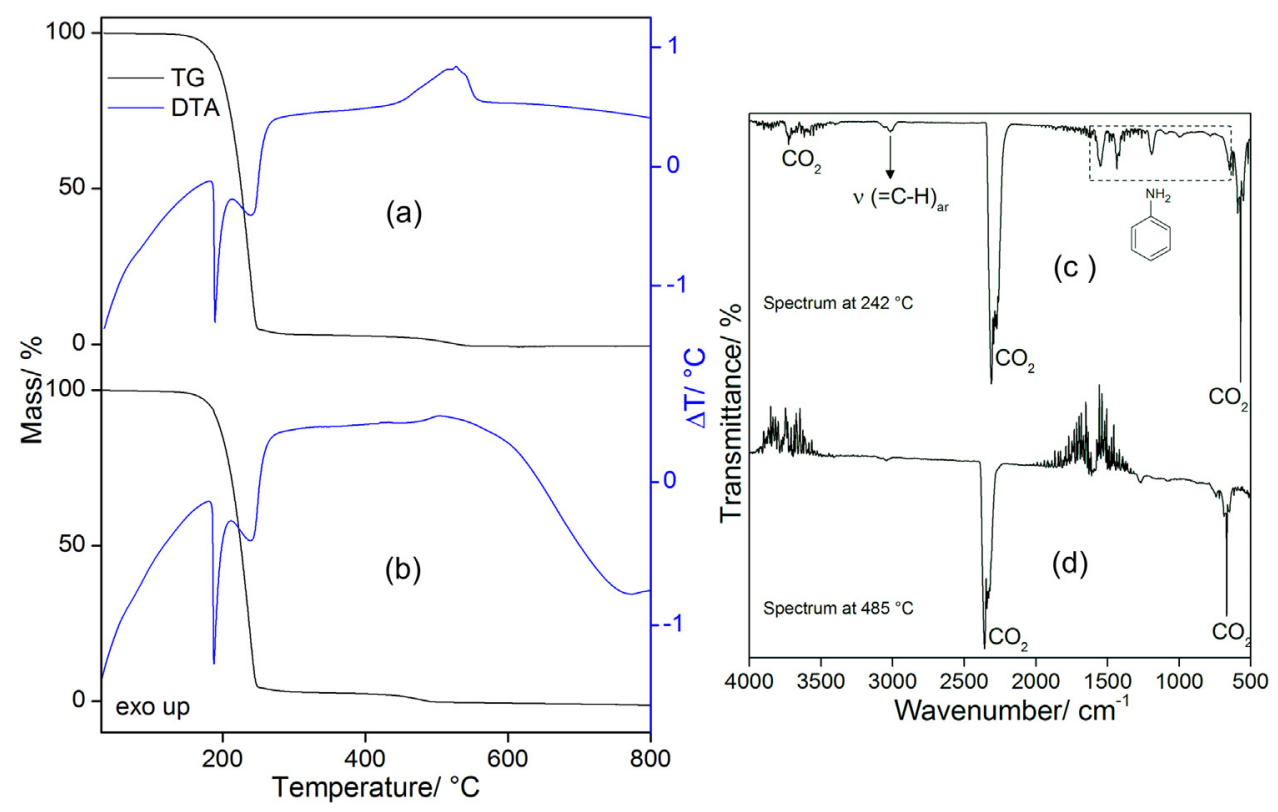

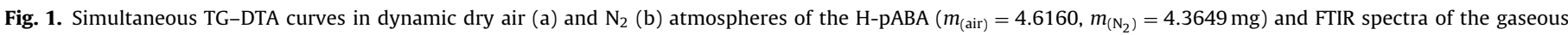
products evolved during thermal decomposition of the $\mathrm{H}-\mathrm{pABA}$ at $242^{\circ} \mathrm{C}$ (c) and $485^{\circ} \mathrm{C}$ (d).

and $746\left(\delta_{\mathrm{CCN}}\right) \mathrm{cm}^{-1}$, which were assigned to the vibration modes of $\mathrm{CO}_{2}$ and aniline molecules, respectively [22]. As previously discussed, the acid lost mass mainly due to physical phenomena, thus the EGA results suggest that decarboxylation should have occurred in the gaseous state, probably in the heated transfer line $\left(225^{\circ} \mathrm{C}\right)$. $\mathrm{CO}_{2}$ was detected in the last step of mass loss (Fig. 1d), which was attributed to the oxidation (air) or pyrolysis $\left(\mathrm{N}_{2}\right)$ of the carbonized residue.

\subsubsection{Na-pABA}

The TG-DTA curves in dynamic dry air and $\mathrm{N}_{2}$ atmospheres for Na-pABA are shown in Fig. 2a and b. These curves showed mass losses in three steps between $60-780^{\circ} \mathrm{C}$ (air) and $60-800^{\circ} \mathrm{C}\left(\mathrm{N}_{2}\right)$

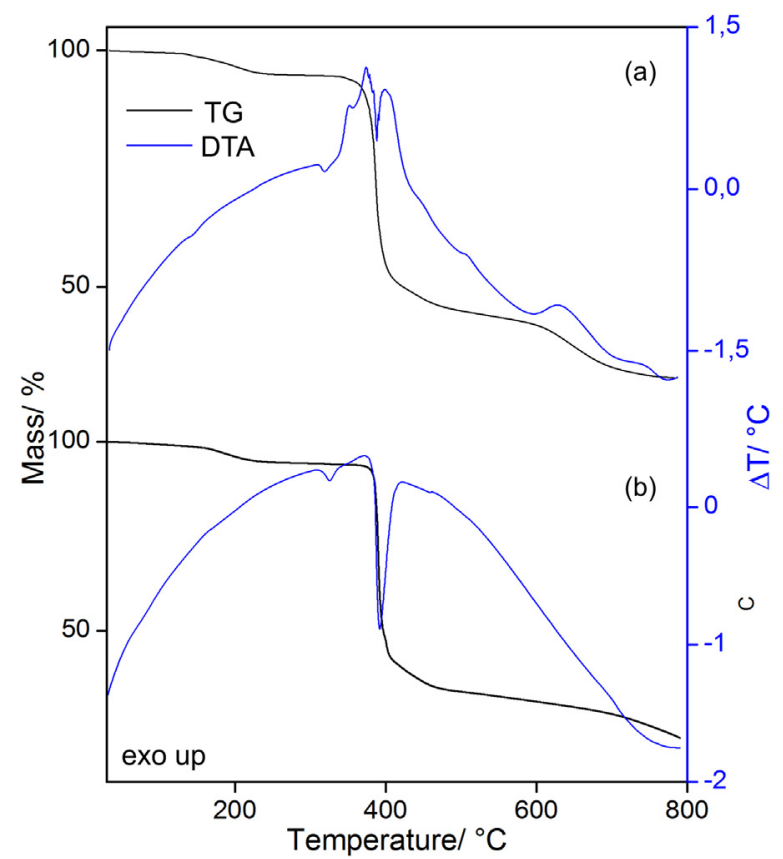

Fig. 2. Simultaneous TG-DTA curves in dynamic dry air (a) and $\mathrm{N}_{2}$ (b) atmospheres of the Na-pABA $\left(m_{(\mathrm{air})}=4.0309 \mathrm{E}, m_{\left(\mathrm{N}_{2}\right)}=4.0924 \mathrm{mg}\right)$. and thermal events corresponding to these losses or the absence of a thermal event. In both atmospheres the first mass loss that occurred slowly, between $60-240^{\circ} \mathrm{C}$ (air) or $60-250^{\circ} \mathrm{C}\left(\mathrm{N}_{2}\right)$ with an indicium of endothermic event at $145^{\circ} \mathrm{C}$ (air) or without a thermal event $\left(\mathrm{N}_{2}\right)$, was attributed to dehydration, with loss of $0.5 \mathrm{H}_{2} \mathrm{O}$ (Calcd. $=5.36 \%$; $\mathrm{TG}=5.28 \%$ (air), 5.58\% $\left(\mathrm{N}_{2}\right)$ ).

The anhydrous compound was stable up to $335^{\circ} \mathrm{C}$ (air) and $370{ }^{\circ} \mathrm{C}\left(\mathrm{N}_{2}\right)$; above this temperature in both atmospheres thermal decomposition occurred in two consecutive steps.

In air atmosphere, the mass loss occurred between $335-485^{\circ} \mathrm{C}$ and $485-780^{\circ} \mathrm{C}$, with a loss of $49.52 \%$ and $14.42 \%$, corresponding to an exothermic event with three peaks at $355^{\circ} \mathrm{C}, 375^{\circ} \mathrm{C}$, $400^{\circ} \mathrm{C}$ (first step) and $630^{\circ} \mathrm{C}$ (second step). This was attributed to oxidation of the organic matter and/or of the gaseous products which evolved during the thermal decomposition and oxidation of the carbonaceous residue, respectively. The total mass loss up to $780^{\circ} \mathrm{C}$ suggests the formation of sodium carbonate as residue (Calcd. $=68.45 \%$; $\mathrm{TG}=68.22 \%$ ), which was confirmed by testing with hydrochloric acid solution on the final residue of the thermal decomposition.

For the $\mathrm{N}_{2}$ atmosphere, the mass loss occurred between $370-470^{\circ} \mathrm{C}$ and $470->795^{\circ} \mathrm{C}$, with losses of $59.33 \%$ and $13.41 \%$, corresponding to an endothermic peak at $395^{\circ} \mathrm{C}$ (first step anhydrous salt) and without a thermal event (second step anhydrous salt). This was attributed to the thermal decomposition and pyrolysis of the carbonaceous residue, in spite of mass loss still being observed up to $795^{\circ} \mathrm{C}$. The endothermic peak at $330^{\circ} \mathrm{C}$ (Fig. 2), without mass loss in the TG curves in both atmospheres, was attributed to reversible phase transformation, and this was confirmed by X-ray diffractometry and the DSC-photovisual heating and cooling curves (see Figs. 1S and 2S Supplementary material). The images obtained in the DSC-photovisual system showed no visual evidence related to decomposition, oxidation and/or melting of the sample, was only observed a slight color change. This allows to state that the observed endothermic peak at $330^{\circ} \mathrm{C}$ is due to a phase transformation intrinsic of the compound. The DSC heating and cooling curve of the Na-pABA heated up to $350^{\circ} \mathrm{C}$ (Fig. 3S Supplementary material) also showed an endothermic peak at $280^{\circ} \mathrm{C}$ (heating) and an exothermic peak at $264^{\circ} \mathrm{C}$ (cooling), confirming the reversibility of the phase transformation. 
Table 1

Analytical and thermoanalytical (TG) data for $\operatorname{Ln}(\mathrm{L})_{3} \cdot \mathrm{H}_{2} \mathrm{O}$ compounds.

\begin{tabular}{|c|c|c|c|c|c|c|c|c|c|c|c|c|c|c|}
\hline \multirow[t]{2}{*}{ Compound } & \multicolumn{3}{|c|}{ Ln oxide (\%) } & \multicolumn{2}{|c|}{$\mathrm{L}($ lost $)(\%)$} & \multicolumn{2}{|c|}{ Water (\%) } & \multicolumn{2}{|l|}{$\mathrm{C}(\%)$} & \multicolumn{2}{|l|}{$\mathrm{N}(\%)$} & \multicolumn{2}{|l|}{$\mathrm{H}(\%)$} & \multirow[t]{2}{*}{ Final Residue } \\
\hline & Calcd. & EDTA & TG & Calcd. & TG & Calcd. & TG & Calcd. & EA & Calcd. & EA & Calcd. & EA & \\
\hline $\mathrm{La}(\mathrm{L})_{3} \cdot \mathrm{H}_{2} \mathrm{O}$ & 28.82 & 29.01 & 28.86 & 67.99 & 67.87 & 3.19 & 3.27 & 44.61 & 44.42 & 7.43 & 7.50 & 3.75 & 3.78 & $\mathrm{La}_{2} \mathrm{O}_{3}$ \\
\hline $\mathrm{Ce}(\mathrm{L})_{3} \cdot \mathrm{H}_{2} \mathrm{O}$ & 30.38 & 30.22 & 30.16 & 66.44 & 66.74 & 3.18 & 3.10 & 44.52 & 44.72 & 7.42 & 7.35 & 3.74 & 3.80 & $\mathrm{CeO}_{2}$ \\
\hline $\operatorname{Pr}(\mathrm{L})_{3} \cdot \mathrm{H}_{2} \mathrm{O}$ & 30.01 & 29.81 & 30.26 & 66.81 & 66.44 & 3.18 & 3.30 & 44.45 & 44.21 & 7.41 & 7.50 & 3.74 & 3.85 & $\mathrm{Pr}_{6} \mathrm{O}_{11}$ \\
\hline $\mathrm{Nd}(\mathrm{L})_{3} \cdot \mathrm{H}_{2} \mathrm{O}$ & 29.49 & 29.36 & 29.26 & 66.74 & 67.09 & 3.77 & 3.65 & 44.19 & 44.43 & 7.36 & 7.30 & 3.72 & 3.80 & $\mathrm{Nd}_{2} \mathrm{O}_{3}$ \\
\hline $\mathrm{Sm}(\mathrm{L})_{3} \cdot \mathrm{H}_{2} \mathrm{O}$ & 30.23 & 30.14 & 30.47 & 65.54 & 65.54 & 4.03 & 3.99 & 43.73 & 43.59 & 7.29 & 7.21 & 3.68 & 3.90 & $\mathrm{Sm}_{2} \mathrm{O}_{3}$ \\
\hline
\end{tabular}

* TG in air atmosphere, $\mathrm{L}=p$-aminobenzoate.

The gaseous products which evolved during thermal decomposition were also monitored by FTIR (see Fig. $4 \mathrm{~S}$ (air) and $4 \mathrm{~S}^{*}\left(\mathrm{~N}_{2}\right)$ Supplementary material). In both the atmospheres $\mathrm{H}_{2} \mathrm{O}$ (dehydration) ca. $170^{\circ} \mathrm{C}$; $\mathrm{CO}, \mathrm{CO}_{2}, \mathrm{NH}_{3}$ and aniline were released during thermal decomposition.

\subsubsection{Lanthanide compounds}

The analytical and thermoanalytical (TG) data for the synthesized compounds are shown in Table 1 . These results established the stoichiometry of the compounds, which were in agreement with the general formula: $\mathrm{Ln}(\mathrm{L})_{3} \cdot \mathrm{H}_{2} \mathrm{O}$, where $\mathrm{Ln}$ represents lighter trivalent lanthanides and $\mathrm{L}$ is $p$-aminobenzoate.

The simultaneous thermogravimetry and differential thermal analysis (TG-DTA) curves of the synthesized compounds in dry air and $\mathrm{N}_{2}$ atmospheres are shown in Fig. 3a-e and $\mathrm{a}^{*}-\mathrm{e}^{*}$, respectively. In air atmosphere these curves exhibited mass losses in two (Ce), three (Pr, Nd, Sm) and four (La) steps and indicated an endothermic event and exothermic peaks or without thermal events. For
$\mathrm{N}_{2}$ atmosphere, these curves showed mass loss in three (La, Ce, Pr, $\mathrm{Sm}$ ) and four (Nd) steps and endothermic peaks, or the absence of thermal events. Because the TG-DTA profiles were characteristic of each atmosphere, they are presented based on the atmosphere which was used.

3.1.3.1. TG-DTA in air atmosphere. A great similarity was noted concerning the TG-DTA curves of these compounds up to $370^{\circ} \mathrm{C}$ (Ce), $395^{\circ} \mathrm{C}$ (La) and $410^{\circ} \mathrm{C}(\mathrm{Pr}$, Nd and Sm). Above these temperatures similarity was only observed for neodymium and samarium.

These curves also showed that, except for cerium, the first mass loss occurred within the same temperature range (i.e. $90-190{ }^{\circ} \mathrm{C}$ ) and the second mass loss also began at the same temperature, showing that the thermal behavior up to this temperature was not dependent on the nature of the lanthanide ion. However, the features shown by the next steps of thermal decomposition, as well as the mass loss in each of the steps, were characteristic of each compound and depends on the lanthanide ion present.
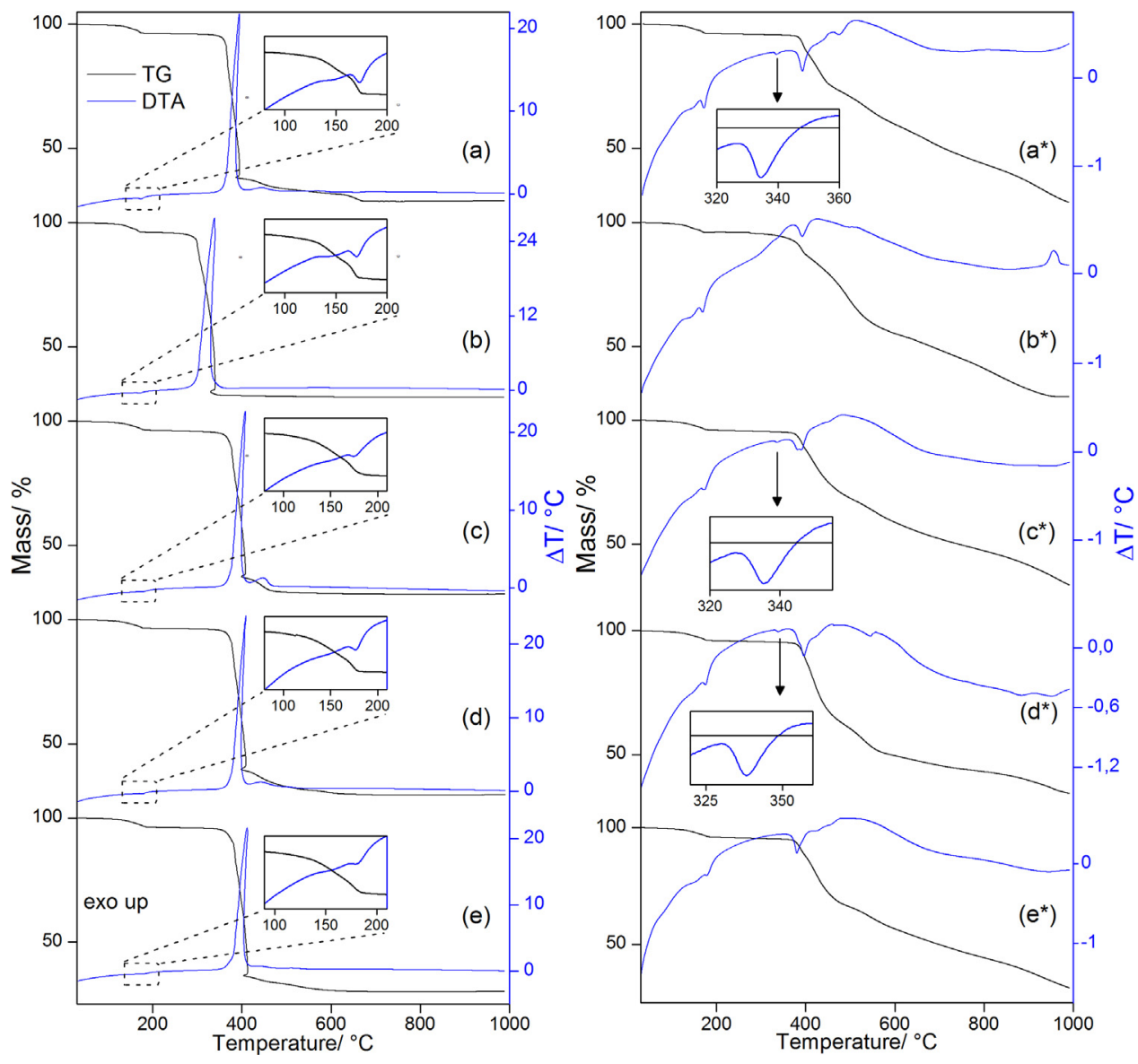

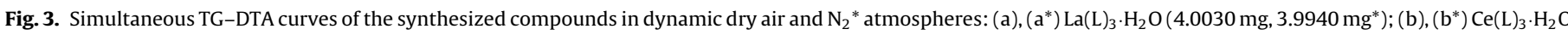

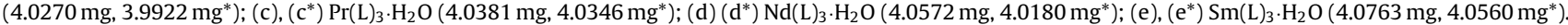


Thus, the features of each of these compounds are discussed on the basis of their similar thermal profiles.

3.1.3.1.1. Lanthanum compound. The TG-DTA curves are shown in Fig. 3a. The first mass loss that occurred through a slow process between 90 and $190^{\circ} \mathrm{C}(\mathrm{TG})$, corresponded to a small endothermic peak at $175^{\circ} \mathrm{C}(\mathrm{DTA})$ was attributed to dehydration, with the loss of $1 \mathrm{H}_{2} \mathrm{O}$ (Calcd. $=3.19 \%$; $\mathrm{TG}=3.27 \%$ ).

The anhydrous compound was stable up to $330^{\circ} \mathrm{C}$ and above this temperature up to $680^{\circ} \mathrm{C}$, the thermal decomposition occurred in three consecutive steps. The first one occurred between 330 and $400^{\circ} \mathrm{C}$, which corresponded to a sharp exothermic peak at $395^{\circ} \mathrm{C}$ and which was attributed to oxidation of organic matter and/or of the gaseous products that evolved during thermal decomposition, with loss of $58.08 \%$ and the formation of a mixture of carbonaceous residue and a derivative of carbonate. The formation of this mixture was confirmed by tests with hydrochloric acid solution on samples heated up to $400^{\circ} \mathrm{C}$, as indicated by the TG-DTA curves, confirming the elimination of $\mathrm{CO}_{2}$ and the presence of carbonaceous residue.

The second step, between 400 and $500{ }^{\circ} \mathrm{C}$ and with loss of $4.42 \%$ corresponding to a small exothermic event, was attributed to the partial oxidation of the carbonaceous residue, which was formed in the former step. The last step, between 500 and $680^{\circ} \mathrm{C}$, began through a slow process, followed by a fast one, with loss of $5.37 \%$ and without any thermal event. It was attributed to the final oxidation of the carbonaceous residue together with the thermal decomposition of the derivative of carbonate, probably dioxycarbonate, as already observed for other lanthanide compounds [18]. No thermal event corresponding to the last mass loss (TG) was observed in the DTA curve, probably because in this step occurred the oxidation of carbonaceous residue (exo) and thermal decomposition of derivative of carbonate (endo), and the produced heat was not sufficient to produce a thermal event. The total mass loss up to $690^{\circ} \mathrm{C}$ was in agreement with the formation of lanthanide oxide $\left(\mathrm{La}_{2} \mathrm{O}_{3}\right)$ as final residue (Calcd. $=71.18 \%$; $\mathrm{TG}=71.14 \%$ ).

3.1.3.1.2. Cerium compound. The TG-DTA curves are shown in Fig. 3b. The first mass loss was observed between 90 and $180^{\circ} \mathrm{C}$, corresponding to an indicium of an endothermic event at $170^{\circ} \mathrm{C}$, was attributed to dehydration, with loss of $1 \mathrm{H}_{2} \mathrm{O}$ (Calcd. $=3.18 \%$; $\mathrm{TG}=3.10 \%$ ).

The anhydrous compound was stable up to $250^{\circ} \mathrm{C}$ and above this temperature up to $370^{\circ} \mathrm{C}$. Thermal decomposition occurred in a single step, with loss of $66.74 \%$, which corresponding to a sharp exothermic peak, which was attributed to the oxidation reaction of the $\mathrm{Ce}(\mathrm{III})$ to $\mathrm{Ce}(\mathrm{IV})$, of organic matter and/or of the gaseous products that evolved during the thermal decomposition. The total mass loss up to $370^{\circ} \mathrm{C}$ was in agreement with the formation of cerium oxide $\left(\mathrm{CeO}_{2}\right)$ as final residue (Calcd. $=69.62 \%$; $\mathrm{TG}=69.84 \%$ ). The lower thermal stability of the cerium compound, as well as the thermal decomposition of the anhydrous compound in a single step, was undoubtedly due to the oxidation reaction of $\mathrm{Ce}$ (III) to $\mathrm{Ce}(\mathrm{IV})$, of the organic matter and/or of the gaseous products evolved during the thermal decomposition. This behavior has already been observed in other cerium compounds [23].

3.1.3.1.3. Praseodymium compound. The TG-DTA curves are shown in Fig. 3c. The first mass loss occurred slowly between 90 and $190^{\circ} \mathrm{C}$, without a definite endothermic peak (DTA) and was attributed to dehydration with loss of $1 \mathrm{H}_{2} \mathrm{O}$ (Calcd. $=3.18 \%$; TG $=3.30 \%$ ).

The anhydrous compound was stable up to $330^{\circ} \mathrm{C}$ and above this temperature up to $520^{\circ} \mathrm{C}$; thermal decomposition occurred in two consecutive steps. The first step between 330 and $410^{\circ} \mathrm{C}$, with loss of $60.37 \%$, corresponding to a sharp exothermic peak at $410^{\circ} \mathrm{C}$, was attributed to the oxidation of the organic matter and/or of the gaseous products that evolved during thermal decomposition and of $\operatorname{Pr}\left(\right.$ III) to $\operatorname{Pr}_{6} \mathrm{O}_{11}$.
The second step between 410 and $520^{\circ} \mathrm{C}$, with loss of $6.07 \%$ corresponding to an exothermic peak, was attributed to the oxidation of the carbonaceous residue formed in the former step. No derivative of carbonate was observed in the decomposition of this compound, probably due to the oxidation reaction of $\operatorname{Pr}(\mathrm{III})$ to $\operatorname{Pr}_{6} \mathrm{O}_{11}$ and of the carbonaceous residue. The total mass loss up to $520^{\circ} \mathrm{C}$ was in agreement with the formation of praseodymium oxide $\left(\mathrm{Pr}_{6} \mathrm{O}_{11}\right)$ as final residue (Calcd. $=69.99 \mathrm{X}$; $\mathrm{TG}=69.74 \%$ ).

3.1.3.1.4. Neodymium and samarium compounds. The TG-DTA curves are shown in Fig. $3 \mathrm{~d}$ and e. In both compounds, the first mass loss between 90 and $190^{\circ} \mathrm{C}(\mathrm{Nd}), 195^{\circ} \mathrm{C}(\mathrm{Sm})$ occurred slowly, without a defined endothermic peak. This was attributed to dehydration with the loss of $1 \mathrm{H}_{2} \mathrm{O}$ for both compounds ( $\mathrm{Nd}$ : Calcd. $=3.77 \%$, $\mathrm{TG}=3.65 \%$; Sm: Calcd. $=4.03 \%$, TG $=3.99 \%$ ).

The anhydrous compounds were stable up to $330^{\circ} \mathrm{C}$ and above this temperature up to $690^{\circ} \mathrm{C}$. The thermal decomposition occurred in two consecutive steps. The first step was a fast process, between $330-405^{\circ} \mathrm{C}(\mathrm{Nd})$ and $330-410^{\circ} \mathrm{C}(\mathrm{Sm})$, with loss of $57.63 \%(\mathrm{Nd})$ and $60.01 \%(\mathrm{Sm})$. This corresponded to a sharp exothermic peak at $405^{\circ} \mathrm{C}(\mathrm{Nd})$ and $410^{\circ} \mathrm{C}(\mathrm{Sm})$, which was attributed to the oxidation of organic matter and/or of the gaseous products which evolved during thermal decomposition. The last step between $405-690^{\circ} \mathrm{C}$ (Nd) and $410-690^{\circ} \mathrm{C}(\mathrm{Sm})$, with loss of $9.46 \%$ and $5.53 \%$, corresponded to small exothermic events in the beginning of the mass loss at $445^{\circ} \mathrm{C}$ and $450^{\circ} \mathrm{C}$, respectively, and without no thermal event above this temperature suggests that the last mass loss occurred through two overlapping steps attributed to oxidation of carbonaceous residue and the thermal decomposition of a derivate of carbonate, which was formed in the former step. The total mass losses up to $690^{\circ} \mathrm{C}$ were in agreement with the formation of the respective oxides, $\mathrm{Nd}_{2} \mathrm{O}_{3}$ and $\mathrm{Sm}_{3} \mathrm{O}_{3}$, (Nd: Calcd. $=70.51 \%$, $\mathrm{TG}=70.74 \%$; Sm: Calcd. $=69.77 \%, \mathrm{TG}=69.53 \%$ ).

For all the compounds, the discontinuity observed in the TG curves and the inclination of the DTA curves, which were observed in the final of the first mass loss of anhydrous compounds, were undoubtedly due to the oxidation of organic matter and/or of the gaseous products that evolved during the thermal decomposition, which occurred with combustion.

3.1.3.2. TG-DTA in nitrogen atmosphere. For all the compounds, the first mass loss up to $180^{\circ} \mathrm{C}$ ( $\mathrm{La}, \mathrm{Ce}$ ) or $190^{\circ} \mathrm{C}$ ( $\left.\mathrm{Pr}, \mathrm{Nd}, \mathrm{Sm}\right)$ began with a slow process, followed by a fast one, which corresponded to an indicium of an endothermic event at $140^{\circ} \mathrm{C}$ ( $\mathrm{La}, \mathrm{Ce}, \mathrm{Pr}$ ) or $145^{\circ} \mathrm{C}(\mathrm{Nd}, \mathrm{Sm})$ and an endothermic peak at $170^{\circ} \mathrm{C}(\mathrm{Ce}), 175^{\circ} \mathrm{C}(\mathrm{La}$, $\mathrm{Pr})$ and $180^{\circ} \mathrm{C}(\mathrm{Nd}, \mathrm{Sm})$. This was attributed to dehydration with loss of $1 \mathrm{H}_{2} \mathrm{O}$ (La to Sm: Calcd. $=3.19 \%, 3.18 \%, 3.18 \%, 3.77 \%, 4.03 \%$; TG $=3.20 \%, 3.15 \%, 3.25 \%, 3.85 \%$ and $3.90 \%$, respectively).

The anhydrous compounds were stable up to $275^{\circ} \mathrm{C}(\mathrm{Ce}), 365^{\circ} \mathrm{C}$ ( $\mathrm{Pr}, \mathrm{Nd}, \mathrm{Sm})$ and $370^{\circ} \mathrm{C}(\mathrm{La})$, and above this temperature the thermal decomposition occurred in two ( $\mathrm{La}, \mathrm{Ce}, \mathrm{Pr}, \mathrm{Sm}$ ) and three (Nd) consecutives steps. A great similarity was observed regarding the TG profiles of the lanthanum, praseodymium and samarium compounds, (Fig. 3a*, $c^{*}$ and $e^{*}$ ). On the other hand, cerium and neodymium displayed TG profiles that were characteristic of each compound (Fig. 3b* and $\mathrm{d}^{*}$ ).

3.1.3.2.1. Lanthanum compound. For the lanthanum compound, the mass loss occurred between $370-450{ }^{\circ} \mathrm{C}$ and $450-990^{\circ} \mathrm{C}$ with loss of $20.10 \%$ and $47.91 \%$ corresponding to endothermic peaks at $395^{\circ} \mathrm{C}$ and $480^{\circ} \mathrm{C}$, which was attributed to the thermal decomposition and pyrolysis of the carbonaceous residue, respectively. The total mass loss up to $990^{\circ} \mathrm{C}$ was in agreement with the formation of lanthanum oxide, $\mathrm{La}_{2} \mathrm{O}_{3}$, as final residue (Calcd. $=71.18 \%$; TG $=71.21 \%$ ).

3.1.3.2.2. Praseodymium and Samarium compounds. In the case of the praseodymium and samarium compounds, the mass losses occurred between $365-490^{\circ} \mathrm{C}$ and $490->990^{\circ} \mathrm{C}$ with losses of 

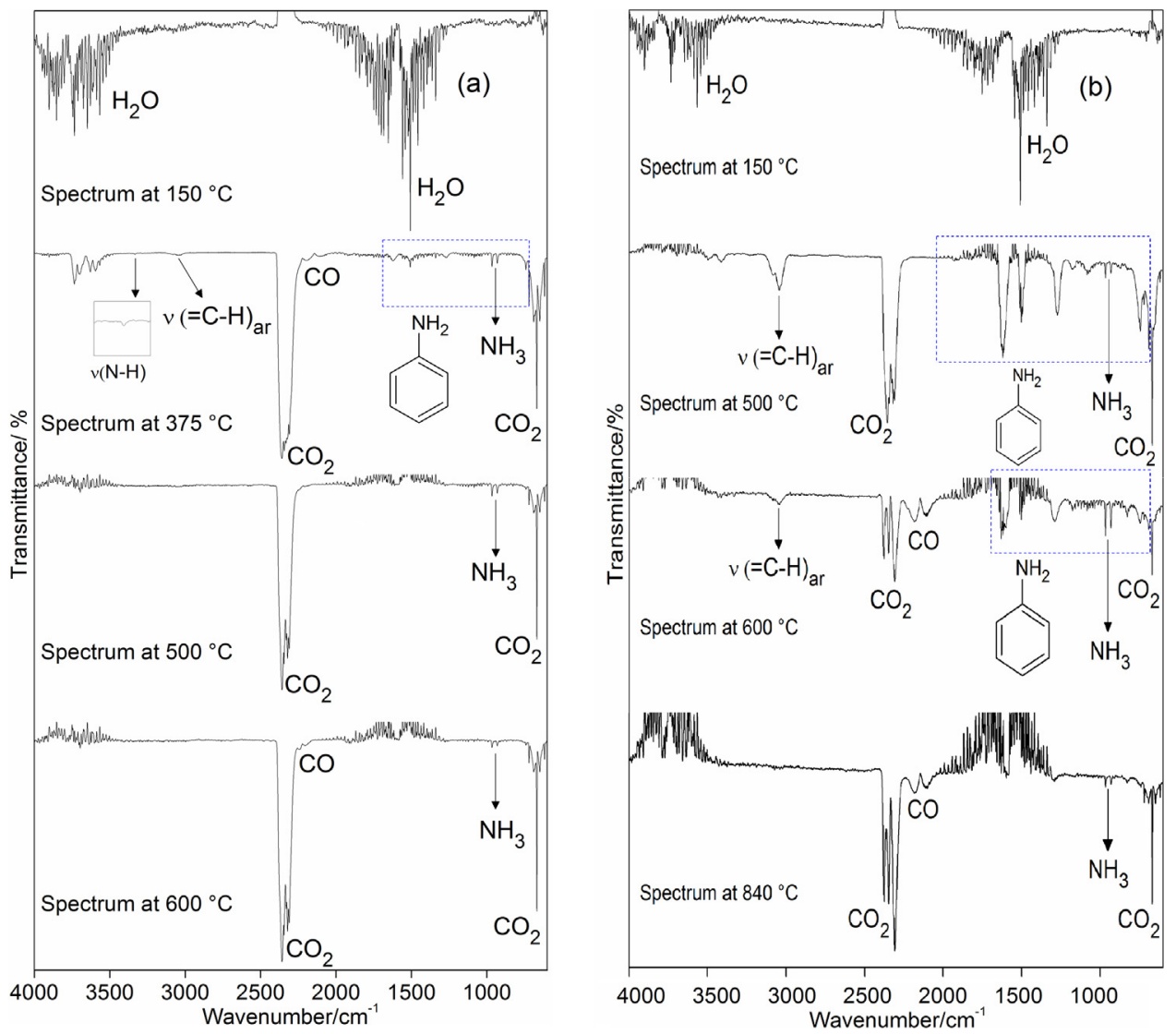

Fig. 4. MIR spectra from the gaseous products evolved during the thermal decomposition of Lanthanum compound in dynamic dry air (a) and $\mathrm{N}_{2}$ (b) atmospheres.

21.82\% and $40.96 \%(\mathrm{Pr})$ and $27.89 \%$ and $36.18 \%(\mathrm{Sm})$, corresponding to an endothermic peak at $390^{\circ} \mathrm{C}(\mathrm{Pr})$ and $385^{\circ} \mathrm{C}(\mathrm{Sm})$, which was attributed to thermal decomposition. No thermal event corresponding to the last mass loss was observed in the DTA curves, probably because the mass loss occurred slowly and the heat involved in the pyrolysis of the carbonaceous residue was not sufficient to produce a thermal event. In both compounds, mass loss was still being observed up to $990^{\circ} \mathrm{C}$.

3.1.3.2.3. Cerium compound. For the cerium compound, the mass loss occurred in two steps between $275-590^{\circ} \mathrm{C}$ and $590-970^{\circ} \mathrm{C}$ with losses of $40.0 \%$ and $26.39 \%$, corresponding to an endothermic peak at $395^{\circ} \mathrm{C}$, which was attributed to thermal decomposition. No thermal event was observed in the DTA curve corresponding to the last mass loss. The total mass loss up to $970{ }^{\circ} \mathrm{C}$ was in agreement with the formation of cerium oxide, $\mathrm{CeO}_{2}$, as final residue (Calcd. $=69.62 \%$; $\mathrm{TG}=69.54 \%$ ). The exothermic peak at $970^{\circ} \mathrm{C}$ was attributed to the oxidation reaction of $\mathrm{Ce}(\mathrm{III})$ to $\mathrm{Ce}(\mathrm{IV})$.

3.1.3.2.4. Neodymium compound. For the neodymium compound, the mass loss occurred in three steps, between $400-470^{\circ} \mathrm{C}$, $470-580^{\circ} \mathrm{C}$ and $580->990^{\circ} \mathrm{C}$, with losses of $27.78 \%, 17.41 \%$ and $16.07 \%$. The first two steps corresponded to endothermic peaks at $400^{\circ} \mathrm{C}$ and $550^{\circ} \mathrm{C}$, which was attributed to thermal decomposition. The last step occurred slowly with two endothermic events at $885^{\circ} \mathrm{C}$ and $960^{\circ} \mathrm{C}$ and was attributed to pyrolysis of the carbonaceous residue, in spite of the fact that mass loss was still being observed up to $990^{\circ} \mathrm{C}$.

The endothermic peak at $335^{\circ} \mathrm{C}(\mathrm{La})$ and $340^{\circ} \mathrm{C}(\mathrm{Pr}, \mathrm{Nd})$, without mass loss in the TG curve, was attributed to a reversible phase transformation, which was confirmed by the DSC-photovisual (heating and cooling curve) and X-ray diffractometry (see Figs. 5S-7S (DSC) and 8S (DRX) Supplementary material and video (La)). As for the Na-pABA the imagens obtained in the DSC-photovisual system showed no visual evidence related to decomposition, oxidation and/or melting of the sample for the La, Pr and $\mathrm{Nd}$ compounds. However, a change in color of the sample after endothermic peak was observed, which can be an evidence for a change in the crystalline structure. The exothermic event related to the reversible process was not observed, probably because the transition occurred so slowly that the heat released in this event was not sufficient to produce a thermal event in the DSC curve [24]. Furthermore, the Xray diffraction powder patterns for anhydrous compounds ( $\mathrm{La}, \mathrm{Pr}$ and $\mathrm{Nd}$ ) were the same after being heated up to $350^{\circ} \mathrm{C}$ and cooled to ambient temperature. The X-ray diffraction powder pattern for the neodymium compound are representative of all the compounds, see Fig. 8S Supplementary material.

\subsection{4. $E G A$}

The IR spectra, which were selected at different temperatures for the gaseous products that evolved during the thermal decomposition of the lanthanum compound in air and $\mathrm{N}_{2}$ atmospheres, are presented in Fig. $4 a$ (air) and $b\left(\mathrm{~N}_{2}\right)$, respectively; they are representative of all the compounds because the gases that were released were the same. The main gaseous products that evolved in both atmospheres were $\mathrm{H}_{2} \mathrm{O}$ in the dehydration step, and $\mathrm{CO}, \mathrm{CO}_{2}, \mathrm{NH}_{3}$ and aniline during the thermal decomposition of the compounds.

\subsection{5. $D S C$}

The DSC curves in nitrogen atmosphere of Na-pABA and the synthesized compounds are shown in Fig. 5.

These curves show endothermic peaks, which were all in accordance with the thermal events observed in the DTA curves up to $350^{\circ} \mathrm{C}$. The endothermic peaks at $182^{\circ} \mathrm{C}(\mathrm{La}), 176^{\circ} \mathrm{C}(\mathrm{Ce}), 180^{\circ} \mathrm{C}$ $(\mathrm{Pr}), 181^{\circ} \mathrm{C}(\mathrm{Nd})$ and $183^{\circ} \mathrm{C}(\mathrm{Sm})$, as well as the thermal event between 166 and $260^{\circ} \mathrm{C}(\mathrm{Na})$ were attributed to dehydration. The 


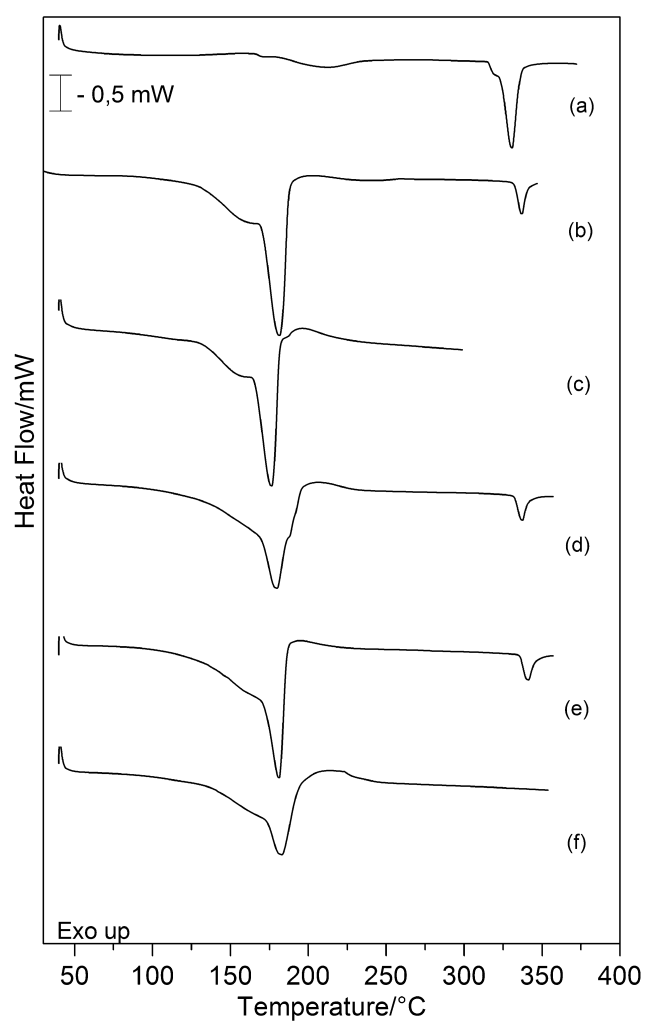

Fig. 5. $D S C$ curves of (a) Na-pABA, (b) $\mathrm{La}(\mathrm{L})_{3} \cdot \mathrm{H}_{2} \mathrm{O}$, (c) $\mathrm{Ce}(\mathrm{L})_{3} \cdot \mathrm{H}_{2} \mathrm{O}$, (d) $\operatorname{Pr}(\mathrm{L})_{3} \cdot \mathrm{H}_{2} \mathrm{O}$, (e) $\mathrm{Nd}(\mathrm{L})_{3} \cdot \mathrm{H}_{2} \mathrm{O}$ and (f) $\mathrm{Sm}(\mathrm{L})_{3} \cdot \mathrm{H}_{2} \mathrm{O}$.

difference observed in the peak temperature of dehydration in the DTA and DSC curves was undoubtedly due to the experimental conditions, which were not the same. The dehydration enthalpies found for the compounds were: 80.4 (La), $78.8(\mathrm{Ce}), 80.5$ (Pr), 78.5 $(\mathrm{Nd}), 76.2(\mathrm{Sm})$ and $2.6(\mathrm{Na}) \mathrm{kJ} \mathrm{mol}^{-1}$. The endothermic peaks at $337{ }^{\circ} \mathrm{C}(\mathrm{La}, \mathrm{Pr}), 341^{\circ} \mathrm{C}(\mathrm{Nd})$ and $331{ }^{\circ} \mathrm{C}(\mathrm{Na})$ were attributed to phase transformation, and the enthalpies found were: 4.2, 3.8, 4.2 and $4.4 \mathrm{~kJ} \mathrm{~mol}^{-1}$, respectively.

\section{2. $X R D$}

The X-ray diffraction powder patterns showed that all the synthesized compounds had a crystalline structure and there was evidence of the formation of an isomorphous series (see Fig. 9S Supplementary material).

\subsection{Vibrational spectroscopy}

The vibrational transitions of H-pABA and its sodium salt and compounds with lighter trivalent lanthanides were studied in the middle (Table 2) and near (Table 3) infrared regions (see Figs. 10S and $11 \mathrm{~S}$ in Supplementary material).

The strong band at $1662 \mathrm{~cm}^{-1}$ in the MIR spectra of $\mathrm{H}$ pABA was attributed to $\mathrm{C}=\mathrm{O}$ stretching of free acid. The bands at $3460 \mathrm{~cm}^{-1}, 3364 \mathrm{~cm}^{-1}$ (harmonic band at $3381 \mathrm{~cm}^{-1}$ ) and a strong band at $1623 \mathrm{~cm}^{-1}$ were related to the vibrational modes of the $-\mathrm{NH}_{2}$ group (stretching asymmetric, symmetric, and bending, respectively). The $\mathrm{C}-\mathrm{N}$ and $\mathrm{C}-\mathrm{OH}$ stretches were characterized by the occurrence of the bands in the MIR spectrum of $\mathrm{H}-\mathrm{pABA}$ at $1310 \mathrm{~cm}^{-1}(\mathrm{C}-\mathrm{N})$ and $1289 \mathrm{~cm}^{-1}(\mathrm{C}-\mathrm{OH})$ [25-27]. Bands in the region of $3000-2300 \mathrm{~cm}^{-1}$ are related to the intermolecular interactions between the carboxyl and the amino group.

For the MIR spectra of the sodium salt and synthesized compounds, the strong band at $1663 \mathrm{~cm}^{-1},(\nu C=0)$ was not observed. However, the intense bands which were found for the sodium salt at 1538 and $1392 \mathrm{~cm}^{-1}$ were attributed to the asymmetrical and symmetrical frequencies of the carboxylate groups, respectively [28]. The asymmetrical and symmetrical stretching of the carboxylate groups of lanthanide compounds (see Table 2) were located between $1504-1501$ and $1393-1387 \mathrm{~cm}^{-1}$, respectively. The $\Delta v_{\mathrm{CoO}} / v_{\mathrm{as}}-v_{\mathrm{s}}\left(109-115 \mathrm{~cm}^{-1}\right)$ of the lanthanide compounds and sodium salt $\left(\Delta v=146 \mathrm{~cm}^{-1}\right)$ were compared, and the difference observed between them indicated bidentate and/or bridged interaction of ligand with the lanthanide ion [15,17,29].

The vibrational modes of the amino group of lanthanide compounds and sodium salt were compared with H-pABA. The results showed changes in wavenumber for the metal compounds (see Table 2). The $-\mathrm{C}-\mathrm{N}$ stretch of lanthanide compounds occurred at $1293 \mathrm{~cm}^{-1}$ and at $1310 \mathrm{~cm}^{-1}$ for H-pABA. These changes suggest

Table 2

Main vibrational data (MIR) for the $p$-aminobenzoic acid, their sodium salt and lanthanide compounds.

\begin{tabular}{|c|c|c|c|c|c|c|c|}
\hline Assignment [23-26] & H-pABA & Na-pABA. $0.5 \mathrm{H}_{2} \mathrm{O}$ & $\mathrm{La}(\mathrm{L})_{3} \cdot \mathrm{H}_{2} \mathrm{O}$ & $\mathrm{Ce}(\mathrm{L})_{3} \cdot \mathrm{H}_{2} \mathrm{O}$ & $\operatorname{Pr}(\mathrm{L})_{3} \cdot \mathrm{H}_{2} \mathrm{O}$ & $\mathrm{Nd}(\mathrm{L})_{3} \cdot \mathrm{H}_{2} \mathrm{O}$ & $\mathrm{Sm}(\mathrm{L})_{3} \cdot \mathrm{H}_{2} \mathrm{O}$ \\
\hline vas $\mathrm{NH}_{2}$ & $3460_{w}$ & $3377_{w}$ & $3456_{w}$ & $3457_{w}$ & $3457_{w}$ & $3457_{w}$ & $3457_{w}$ \\
\hline vsNH${ }_{2}$ & $3363_{w}$ & $3315_{w}$ & $3373_{w}$ & $3372_{w}$ & $3373_{w}$ & $3374_{w}$ & $3372_{w}$ \\
\hline$\nu \mathrm{OH}$ & $3000-3250_{w}$ & $3223_{w}$ & $3312_{\mathrm{w}}$ & $3318_{w}$ & $3317_{w}$ & $3320_{w}$ & $3289_{w}$ \\
\hline$\nu \mathrm{CH}$ & $3010-3050_{w}$ & $3045 / 3012_{\mathrm{w}}$ & $3119_{w}$ & $3124_{w}$ & $3124_{w}$ & $3126_{w}$ & $3135_{w}$ \\
\hline $\mathrm{N}-\mathrm{H} \cdots \mathrm{O} / \mathrm{O}-\mathrm{H} \cdots \mathrm{N}$ & $2300-3000_{w}$ & & & & & & \\
\hline$\nu \mathrm{C}=\mathrm{O}$ & $1663_{s}$ & & & & & & \\
\hline$\delta \mathrm{NH}_{2}$ & $1623_{\mathrm{m}}$ & $1598_{\mathrm{m}}$ & $1608_{\mathrm{m}}$ & $1608_{\mathrm{m}}$ & $1608_{\mathrm{m}}$ & $1608_{\mathrm{m}}$ & $1608_{\mathrm{m}}$ \\
\hline$\nu \mathrm{C}=\mathrm{C}$ & $1598_{s}$ & & $1587_{\mathrm{m}}$ & $1589_{\mathrm{m}}$ & $1589_{\mathrm{m}}$ & $1589_{\mathrm{m}}$ & $1590_{\mathrm{m}}$ \\
\hline$\nu \mathrm{C}=\mathrm{C}$ & $1574_{\mathrm{m}}$ & & & & & & \\
\hline vasCOO ${ }^{-}$ & & $1538_{\text {vs }}$ & $1502_{\mathrm{vs}}$ & $1501_{\text {vs }}$ & $1501_{\mathrm{vs}}$ & $1502_{\mathrm{vs}}$ & $1504_{\mathrm{vs}}$ \\
\hline$\nu \mathrm{C}=\mathrm{C}$ & $1522_{\mathrm{w}}$ & & & & & & \\
\hline$\nu C=C$ & $1441_{\mathrm{m}}$ & & & & & & \\
\hline$\delta \mathrm{OH}$ & $1421_{\mathrm{m}}$ & & & & & & \\
\hline vsCOO${ }^{-}$ & & $1398_{\mathrm{vs}}$ & $1387_{\text {vs }}$ & $1391_{\text {vs }}$ & $1391_{\mathrm{vs}}$ & $1393_{v s}$ & $1395_{\mathrm{vs}}$ \\
\hline$v C-\mathrm{N}$ & $1310_{s}$ & $1264_{\mathrm{m}}$ & $1293_{m}$ & $1294_{\mathrm{m}}$ & $1294_{\mathrm{m}}$ & $1294_{\mathrm{m}}$ & $1293_{\mathrm{m}}$ \\
\hline$\nu \mathrm{C}-\mathrm{OH}$ & $1289_{\mathrm{vs}}$ & & & & & & \\
\hline$\delta_{\text {out }} \mathrm{NH}_{2}$ & $1072_{\mathrm{vw}}$ & $1084_{\mathrm{vw}}$ & $1088_{\mathrm{vw}}$ & $1088_{\mathrm{vw}}$ & $1088_{\mathrm{vw}}$ & $1087_{\mathrm{vw}}$ & $1087_{\mathrm{vw}}$ \\
\hline$\delta \mathrm{CH}$ & & $1018_{\mathrm{vw}}$ & $1014_{\mathrm{vw}}$ & $1013_{v w}$ & $1014_{\mathrm{vw}}$ & $1015_{\mathrm{vw}}$ & $1014_{v w}$ \\
\hline$\delta_{\text {out }} \mathrm{CH}$ & $842_{\mathrm{m}}$ & $845_{\mathrm{m}}$ & $850_{\mathrm{m}}$ & $849_{\mathrm{m}}$ & $850_{\mathrm{m}}$ & $852_{\mathrm{m}}$ & $852_{\mathrm{m}}$ \\
\hline$\delta_{\text {out }} \mathrm{CH}$ & $770_{\mathrm{vs}}$ & $782_{\mathrm{vs}}$ & $787_{\text {vs }}$ & $786_{\mathrm{vs}}$ & $786_{\mathrm{vs}}$ & $787_{\text {vs }}$ & $786_{\mathrm{vs}}$ \\
\hline$\delta C-C-C$ & $699_{w}$ & $692_{\mathrm{m}}$ & $701_{\mathrm{s}}$ & $701_{\mathrm{s}}$ & $701_{\mathrm{s}}$ & $701_{\mathrm{s}}$ & $700_{s}$ \\
\hline
\end{tabular}

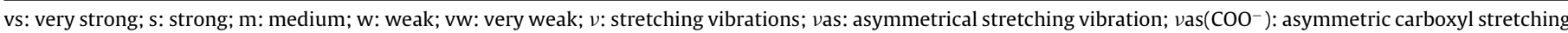
frequency; vs $\left(\mathrm{COO}^{-}\right)$: symmetric carboxyl stretching frequency; $\delta$ : in plane bending vibration. $\delta$ out: out of plane bending vibration 
Table 3

Near infrared bands of the $p$-aminobenzoic acid, their sodium salt and lanthanum compound.

\begin{tabular}{|c|c|c|c|}
\hline Assignment & $\mathrm{H}-\mathrm{pABA}\left(\mathrm{cm}^{-1}\right)$ & Na-pABA $\left(\mathrm{cm}^{-1}\right)$ & $\mathrm{La}(\mathrm{L})_{3} \cdot \mathrm{H}_{2} \mathrm{O}\left(\mathrm{cm}^{-1}\right)$ \\
\hline $3 v \mathrm{NH}$ & 9792 & 9582 & 9730 \\
\hline $3 v \mathrm{CH}_{\text {aromatic }}$ & 8798 & 8848,8755 & 8798 \\
\hline $5 \vee \mathrm{C}=\mathrm{O}_{\text {acid }}$ & 8460,8304 & - & - \\
\hline $\mathrm{OH}_{\text {water }} \mathrm{CB}$ & - & 8200 & 8281 \\
\hline $2 v_{\mathrm{a}} \mathrm{NH}$ & 6885,6852 & - & 6854 \\
\hline $4 v \mathrm{C}=\mathrm{O}_{\text {acid }}$ & 6719 & - & - \\
\hline $2 v_{\mathrm{s}} \mathrm{NH}$ & 6680,6632 & - & 6655,6558 \\
\hline $2 v \mathrm{CH}_{\text {aromatic }}$ & 6003 & 6025 & 6009 \\
\hline $\mathrm{OH}_{\text {water }} \mathrm{CB}$ & - & 5482 & 5509 \\
\hline $\mathrm{NH}$ CB & $5002,4958,4904$ & 4995 & 5046,4989 \\
\hline $\mathrm{CC} \mathrm{CB}$ & $4622,4599,4536$ & $4642,4570,4528$ & $4631,4582,4530$ \\
\hline $\mathrm{CH}_{\text {aromatic }} \mathrm{CB}$ & $4433,4360,4231,4179,4056$ & $4495,4370,4250,4144,4065$ & $4486,4275,4237,4150,4060$ \\
\hline
\end{tabular}

$5 v=4$ th overtone band, $4 v=3$ rd overtone band, $3 v=2$ nd overtone band, $2 v=1$ st overtone band, $C B=$ combination bands.

the interaction of the $-\mathrm{NH}_{2}$ group with metal ion, which was in agreement with Refs. [15,17].

The near infrared region (NIR) spectra of H-pABA, its sodium salt and compounds with lighter trivalent lanthanides, provided information about the combination and overtone bands of the compounds (see Table 3 and Supplementary material). The assignments of the bands were shown for the acid form, the sodium salt and the lanthanum compound. For the other compounds, the assignment of the bands was the same as for lanthanum, differing only for the praseodymium and samarium compounds, which exhibited bands that were assigned to $f$ - $f$ transitions (shown in Table 4). Characteristic water bands appeared in the sodium salt and in the spectra of

Table 4

Absorption bands of the $f-f$ transitions in visible and near infrared regions of the praseodymium, neodymium and samarium compounds

\begin{tabular}{|c|c|c|c|c|}
\hline Complex & Wavenumber $\left(\mathrm{cm}^{-1}\right)$ & Wavelength (nm) & Assignments & Covalent parameters \\
\hline $\operatorname{Pr}(\mathrm{L})_{3} \cdot \mathrm{H}_{2} \mathrm{O}$ & $\begin{array}{r}22,371 \\
21,142 \\
20,661 \\
16,891 \\
9,941 \\
6,771 \\
6,406 \\
5,038\end{array}$ & $\begin{array}{r}447 \\
473 \\
484 \\
592 \\
1005 \\
1477 \\
1561 \\
1985\end{array}$ & $\begin{array}{l}{ }^{3} \mathrm{H}_{4} \rightarrow{ }^{3} \mathrm{P}_{2} \\
{ }^{3} \mathrm{H}_{4} \rightarrow{ }^{3} \mathrm{P}_{1},{ }^{1} \mathrm{I}_{6} \\
{ }^{3} \mathrm{H}_{4} \rightarrow{ }^{3} \mathrm{P}_{0} \\
{ }^{3} \mathrm{H}_{4} \rightarrow{ }^{1} \mathrm{D}_{2} \\
{ }^{3} \mathrm{H}_{4} \rightarrow{ }^{1} \mathrm{G}_{4} \\
{ }^{3} \mathrm{H}_{4} \rightarrow{ }^{3} \mathrm{~F}_{4} \\
{ }^{3} \mathrm{H}_{4} \rightarrow{ }^{3} \mathrm{~F}_{3} \\
{ }^{3} \mathrm{H}_{4} \rightarrow{ }^{3} \mathrm{~F}_{2}^{*}\end{array}$ & $\begin{array}{l}\beta=0.9659 \\
\delta=3.53 \\
b^{1 / 2}=0.1306\end{array}$ \\
\hline $\mathrm{Nd}(\mathrm{L})_{3} \cdot \mathrm{H}_{2} \mathrm{O}$ & $\begin{array}{r}28,409 \\
28,011 \\
23,810 \\
22,988 \\
21,739 \\
21,231 \\
20,964 \\
19,455 \\
19,048 \\
17,094 \\
15,974 \\
14,599 \\
13,333 \\
12,453 \\
11,455\end{array}$ & $\begin{array}{r}352 \\
357 \\
420 \\
435 \\
460 \\
471 \\
477 \\
514 \\
525 \\
585 \\
626 \\
685 \\
737,750 \\
803 \\
873\end{array}$ & $\begin{array}{l}{ }^{4} \mathrm{I}_{9 / 2} \rightarrow{ }^{4} \mathrm{D}_{5 / 2} \\
{ }^{4} \mathrm{I}_{9 / 2} \rightarrow{ }^{4} \mathrm{D}_{3 / 2} \\
{ }^{4} \mathrm{I}_{9 / 2} \rightarrow{ }^{2} \mathrm{D}_{5 / 2} \\
{ }^{4} \mathrm{I}_{9 / 2} \rightarrow{ }^{2} \mathrm{P}_{1 / 2} \\
{ }^{4} \mathrm{I}_{9 / 2} \rightarrow{ }^{4} \mathrm{G}_{11 / 2} \\
{ }^{4} \mathrm{I}_{9 / 2} \rightarrow{ }^{2} \mathrm{G}_{9 / 2},{ }^{2} \mathrm{D}_{3 / 2},{ }^{2} \mathrm{P}_{3 / 2} \\
{ }^{4} \mathrm{I}_{9 / 2} \rightarrow{ }^{2} \mathrm{~K}_{15 / 2} \\
{ }^{4} \mathrm{I}_{9 / 2} \rightarrow{ }^{4} \mathrm{G}_{9 / 2} \\
{ }^{4} \mathrm{I}_{9 / 2} \rightarrow{ }^{4} \mathrm{G}_{7 / 2}{ }^{*} \\
{ }^{4} \mathrm{I}_{9 / 2} \rightarrow{ }^{4} \mathrm{G}_{5 / 2},{ }^{2} \mathrm{G}_{7 / 2} \\
{ }^{4} \mathrm{I}_{9 / 2} \rightarrow{ }^{2} \mathrm{H}_{11 / 2} \\
{ }^{4} \mathrm{I}_{9 / 2} \rightarrow{ }^{4} \mathrm{~F}_{9 / 2} \\
{ }^{4} \mathrm{I}_{9 / 2} \rightarrow{ }^{4} \mathrm{~F}_{7 / 2},{ }^{2} \mathrm{~S}_{3 / 2} \\
{ }^{4} \mathrm{I}_{9 / 2} \rightarrow{ }^{4} \mathrm{~F}_{5 / 2},{ }^{2} \mathrm{H}_{9 / 2} \\
{ }^{4} \mathrm{I}_{9 / 2} \rightarrow{ }^{4} \mathrm{~F}_{3 / 2}\end{array}$ & $\begin{array}{l}\beta=0.9942 \\
\delta=0.58 \\
b^{1 / 2}=0.0538\end{array}$ \\
\hline $\mathrm{Sm}(\mathrm{L})_{3} \cdot \mathrm{H}_{2} \mathrm{O}$ & $\begin{array}{r}28,902 \\
27,548 \\
26,525 \\
25,575 \\
24,752 \\
23,923 \\
22,727 \\
22,173 \\
21,551 \\
21,053 \\
20,877 \\
20,575 \\
19,960 \\
18,868 \\
17,857 \\
10,493 \\
9,156 \\
7,976 \\
7,112 \\
6,622 \\
6,557 \\
6,345\end{array}$ & $\begin{array}{r}346 \\
363 \\
377 \\
391 \\
404 \\
418 \\
440 \\
451 \\
464 \\
475 \\
479 \\
486 \\
501 \\
530 \\
560 \\
953 \\
1092 \\
1253 \\
1406 \\
1510 \\
1525 \\
1576\end{array}$ & $\begin{array}{l}{ }^{6} \mathrm{H}_{5 / 2} \rightarrow{ }^{4} \mathrm{H}_{9 / 2} \\
{ }^{6} \mathrm{H}_{5 / 2} \rightarrow{ }^{4} \mathrm{D}_{3 / 2}+{ }^{4} \mathrm{D}_{52} \\
{ }^{6} \mathrm{H}_{5 / 2} \rightarrow{ }^{4} \mathrm{D}_{1 / 2}+{ }^{4} \mathrm{P}_{7 / 2} \\
{ }^{6} \mathrm{H}_{5 / 2} \rightarrow{ }^{4} \mathrm{~L}_{15 / 2} \\
{ }^{6} \mathrm{H}_{5 / 2} \rightarrow{ }^{4} \mathrm{~L}_{13 / 2}+{ }^{4} \mathrm{~F}_{7 / 2} \\
{ }^{6} \mathrm{H}_{5 / 2} \rightarrow{ }^{6} \mathrm{P}_{9 / 2}+{ }^{4} \mathrm{P}_{5 / 2} \\
{ }^{6} \mathrm{H}_{5 / 2} \rightarrow{ }^{4} \mathrm{G}_{9 / 2}+{ }^{4} \mathrm{I}_{15 / 2} \\
{ }^{6} \mathrm{H}_{5 / 2} \rightarrow{ }^{4} \mathrm{~F}_{5 / 2} \\
{ }^{6} \mathrm{H}_{5 / 2} \rightarrow{ }^{4} \mathrm{I}_{13 / 2} \\
{ }^{6} \mathrm{H}_{5 / 2} \rightarrow{ }^{4} \mathrm{I}_{11 / 2} \\
{ }^{6} \mathrm{H}_{5 / 2} \rightarrow{ }^{4} \mathrm{M}_{15 / 2} \\
{ }^{6} \mathrm{H}_{5 / 2} \rightarrow{ }^{4} \mathrm{I}_{9 / 2} \\
{ }^{6} \mathrm{H}_{5 / 2} \rightarrow{ }^{4} \mathrm{G}_{7 / 2} \\
{ }^{6} \mathrm{H}_{5 / 2} \rightarrow{ }^{4} \mathrm{~F}_{3 / 2} \\
{ }^{6} \mathrm{H}_{5 / 2} \rightarrow{ }^{4} \mathrm{G}_{5 / 2} \\
{ }^{6} \mathrm{H}_{5 / 2} \rightarrow{ }^{6} \mathrm{~F}_{11 / 2} \\
{ }^{6} \mathrm{H}_{5 / 2} \rightarrow{ }^{6} \mathrm{~F}_{9 / 2} \\
{ }^{6} \mathrm{H}_{5 / 2} \rightarrow{ }^{6} \mathrm{~F}_{7 / 2} \\
{ }^{6} \mathrm{H}_{5 / 2} \rightarrow{ }^{6} \mathrm{~F}_{5 / 2} \\
{ }^{6} \mathrm{H}_{5 / 2} \rightarrow{ }^{6} \mathrm{~F}_{3 / 2} \\
{ }^{6} \mathrm{H}_{5 / 2} \rightarrow{ }^{6} \mathrm{H}_{15 / 2} \\
{ }^{6} \mathrm{H}_{5 / 2} \rightarrow{ }^{6} \mathrm{~F}_{1 / 2}\end{array}$ & $\begin{array}{l}\beta=0.9961 \\
\delta=0.39 \\
b^{1 / 2}=0.0442\end{array}$ \\
\hline
\end{tabular}

${ }^{*}$ Hypersensitive transitions. 


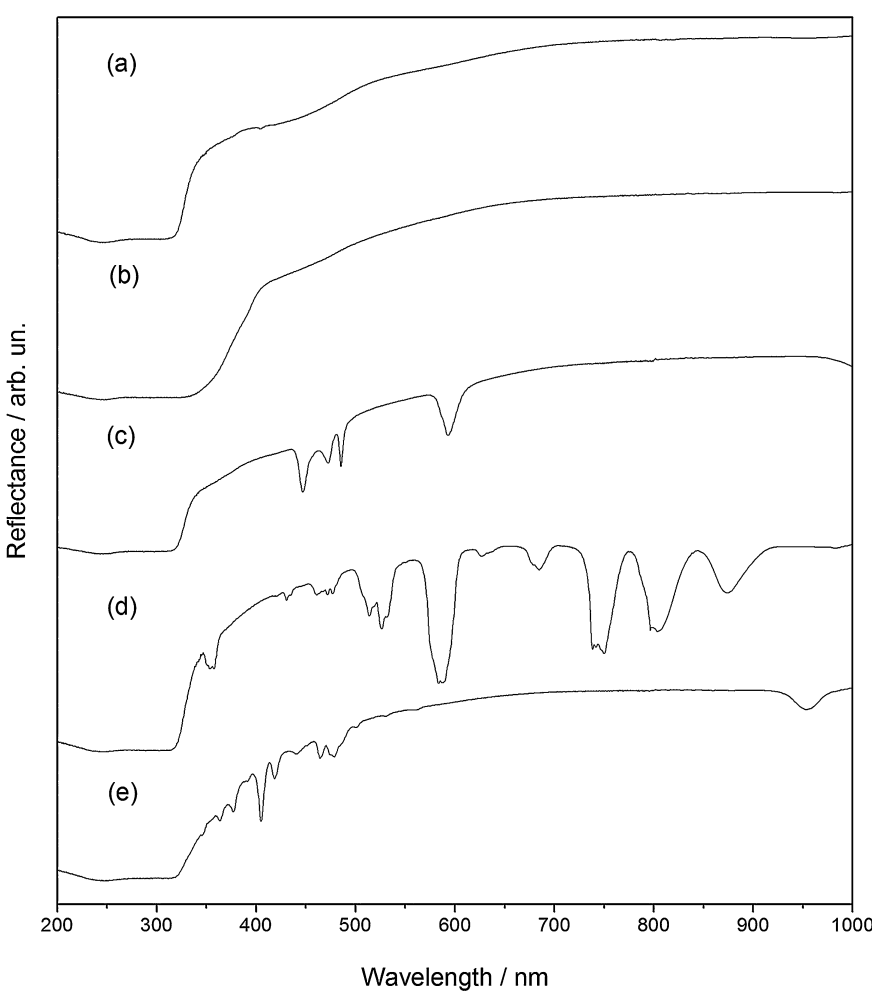

Fig. 6. DR spectra of (a) $\mathrm{La}(\mathrm{L})_{3} \cdot \mathrm{H}_{2} \mathrm{O}$, (b) $\mathrm{Ce}(\mathrm{L})_{3} \cdot \mathrm{H}_{2} \mathrm{O}$, (c) $\operatorname{Pr}(\mathrm{L})_{3} \cdot \mathrm{H}_{2} \mathrm{O}$, (d) $\mathrm{Nd}(\mathrm{L})_{3} \cdot \mathrm{H}_{2} \mathrm{O}$ and (e) $\mathrm{Sm}(\mathrm{L})_{3} \cdot \mathrm{H}_{2} \mathrm{O}$.

the compounds, which was in agreement with the TG-DSC results. Characteristic bands of carboxylic acid only appeared in the acid form, confirming the total deprotonation and the absence of acid contamination in the sodium salt and in the synthesized compounds.

\subsection{Electronic spectroscopy}

The diffuse reflectance (DR) spectra (200-1000 nm) of the $\mathrm{Ln}^{3+}$ compounds ( $\mathrm{Ln}=\mathrm{La}, \mathrm{Ce}, \mathrm{Pr}, \mathrm{Nd}$ and $\mathrm{Sm}$ ) are shown in Fig. 6.

The DR spectra the $\mathrm{Ln}^{3+}$ compounds ( $\mathrm{Ln}=\mathrm{La}, \mathrm{Ce}, \mathrm{Pr}, \mathrm{Nd}$ and $\mathrm{Sm}$ ) exhibited a broad intra-ligand (IL) band in the UV and visible region (200-400 $\mathrm{nm}$ ). In addition, the spectra of $\mathrm{Pr}^{3+}, \mathrm{Nd}^{3+}$ and $\mathrm{Sm}^{3+}$ also showed the typical absorption bands due to $4 f-4 f$ transitions from the ground states to the excited ones of the $\mathrm{Ln}^{3+}$ ions in the $346-1000 \mathrm{~nm}$ spectral range. The lanthanum compound does not present transitions in this region because its core electronic structure has filled shells; consequently, high energies are necessary for to the promotion of an electron from these filled shells. The $\mathrm{Ce}^{3+}$ ion presented characteristic bands in the UV region, which were related to $4 f-5 d$ transitions, but these rarely appear in compounds due to the overlap of the ligand bands [30]. The absorption spectra of the praseodymium compound showed peaks corresponding to the transitions from the ${ }^{3} \mathrm{H}_{4}$ ground state to the excited states. Characteristic absorption bands were also observed in the spectra of the neodymium compound within this spectral range due to transitions from the ${ }^{4} \mathrm{I}_{9 / 2}$ ground state to the excited states. The samarium compound spectra showed peaks corresponding to the transitions from the ${ }^{6} \mathrm{H}_{5 / 2}$ ground state to the excited states. These peaks are presented in Table 4 with the assignment of transitions, and they exhibited shifts in their position compared with the free ions [31]. This shift was related to covalence in the metal-ligand bond, and the parameters related to the covalence, Sinha's parameter $(\delta)$, nephelauxetic ratio $(\beta)$ and bonding parameter $\left(b^{1 / 2}\right)$ are presented in Table 4 . The positive values and the magnitude of these parameters suggest a weak metal-ligand covalent bonding [31]. The higher value of $\beta$ and $b^{1 / 2}$ for the praseodymium compound suggests a higher degree of covalence for this compound compared to the neodymium and samarium compounds.

\section{Conclusion}

Using TG, complexometry and elemental analysis results it was possible to establish a general formula for the synthesized compounds.

The simultaneous TG-DTA and DSC curves provided previously unreported information about the thermal stability and thermal decomposition of these compounds in dynamic dry air and nitrogen atmospheres.

The X-ray powder patterns showed that all the compounds have a crystalline structure, with evidence of the formation of isomorphous compounds.

The middle and near infrared spectroscopic data suggested that both amine and carboxyl groups act as coordination sites.

The DR spectra provided information about the ligand absorption bands and the $f-f$ transitions of $\mathrm{Pr}^{3+}, \mathrm{Nd}^{3+}$ and $\mathrm{Sm}^{3+}$. The shifts in these bands, compared to the free ions, indicated a weak metal-ligand covalent bonding, but the praseodymium complex has a higher degree of covalence when compared to the neodymium and samarium compounds. Praseodymium and samarium also showed $f-f$ transitions in the NIR region.

Using TG-DSC coupled with FTIR (EGA) was possible to identity the gaseous products which evolved during the thermal decomposition of $\mathrm{H}-\mathrm{pABA}$, its sodium salt and the lighter trivalent compounds.

\section{Acknowledgments}

The authors thanks FAPESP (Proc. 2013/09022-7), CNPq, and CAPES foundations (Brazil) for financial support.

\section{Appendix A. Supplementary data}

Supplementary data associated with this article can be found, in the online version, at http://dx.doi.org/10.1016/j.tca.2015.11.023.

\section{References}

[1] Monographs: Medicinal and Pharmaceutical Substances, Aminobenzoic Acid The Stationery Office. 2009.

[2] R.M.E. Richards, D.K.L. Xing, The effect of $p$-aminobenzoic acid on the uptake of thymidine and uracil by Escherichia coli, Int. J. Pharm. 116 (1995) 217-221.

[3] S.I. Akberova, New biological properties of $p$-aminobenzoic acid, Biol. Bull. 29 (2002) 390-393.

[4] F.X. Campos, M.R.S. Soares, A.J. Terezo, A.B. Siqueira, Synthesis, characterization, and antioxidant evaluation of solid-state mefenamates of some bivalent metals, J. Therm. Anal. Calorim. 115 (2014) 167-176.

[5] B.R. Srinivasan, S.C. Sawant, Thermal and spectroscopic characterization of $\mathrm{Mg}(\mathrm{II})$ complexes of nitro-substituted benzoic acids, Thermochim. Acta 402 (2003) 45-55.

[6] A.B. Siqueira, C.T. Carvalho, E.Y. Ionashiro, G. Bannach, E.C. Rodrigues, M. Ionashiro, Synthesis, characterization and thermal behavior of solid 2methoxybenzoates of trivalent metals, J. Therm. Anal. Calorim. 92 (2008) 945-951.

[7] A.L.C.S. Nascimento, F.J. Caires, D.J.C. Gomes, A.C. Gigante, M. Ionashiro, Thermal behavior of nicotinic acid, sodium nicotinate and its compounds whit some bivalents transition metal ions, Thermochim. Acta 575 (2014) 212-218.

[8] H. Tan, C. Ma, L. Chen, F. Xu, S. Chen, L. Wang, Nanoscaled lanthanide/nucleotide coordination polymer for detection of an anthrax biomarker, Sens. Actuators, B: Chem. 190 (2014) 621-626.

[9] J. Shen, L. Zhao, G. Han, Lanthanide-doped upconverting luminescent nanoparticle platforms for optical imaging-guided drug delivery and therapy, Adv. Drug Delivery Rev. 65 (2013) 744-755.

[10] D.A. Gálico, M.G. Lahoud, M.R. Davolos, R.C.C. Frem, T.F.C. Fraga-Silva, J. Venturini, G. Bannach, Spectroscopic, luminescence and in vitro biological studies of solid ketoprofen of heavier trivalent lanthanides and yttrium(III), J. Inorg. Biochem. 140 (2014) 160-166. 
[11] A. Aragón-Muriel, M. Camprubi-Robles, E. González-Rey, A. Salinas-Castillo, A. Rodrígues-Diéguez, S. Gómez-Ruiz, D. Polo-Cerón, Dual investigation of lanthanide complex with cinnamate and phenylacetate ligands: study of the cytotoxic properties and the catalytic oxidation of styrene, Polyhedron 80 (2014) 117-128.

[12] D.A. Gálico, B.B.C. Holanda, R.B. Guerra, A.O. Legendre, D. Rinaldo, O. Treu-Filho, G. Bannach, Thermal and spectroscopic studies on solid ibuprofen complexes of lighter trivalente lanthanides, Thermochim. Acta 575 (2014) 226-232.

[13] D.A. Gálico, B.B.C. Holanda, G.L. Perpétuo, E. Schnitzler, O. Treu-Filho, G. Bannach, Thermal and spectroscopic studies on solid ketoprofen of lighter trivalente lanthanides, J. Therm. Anal. Calorim. 108 (2012) 371-379.

[14] Z. Rzaczynska, W. Brzyska, Complexes of Y, La, and lanthanides with maminobenzoic acid, Mon. Chem. 120 (1989) 231-236.

[15] T. Tsaryuk, A. Vologzhamina, K. Zhuravlev, V. Kudryashova, R. Szostak, V. Zolin, Structures and manifestation of ortho-, meta-, and para- $\mathrm{NH}_{2}-\mathrm{substitution} \mathrm{in}$ the optical spectra of europium and terbium aminobenzoates, J. Photochem. Photobiol., A Chem. 285 (2014) 52-61.

[16] L. Oyang, L.-H. Sun, X.-Y. Wang, J.-R. Li, D.-B. Nie, W.-F. Fu, S. Gao, K.-B. Yu, Crystal structure and luminescence property of ternary terbium $p$-aminobenzoic acid complexes with different second ligands, J. Mol. Struct. 740 (2005) 175-180.

[17] H.-L. Sun, C.-H. Ye, X.-Y. Wang, J.-R. Li, S. Gao, K.-B. Yu, Lanthanide contraction and $\mathrm{pH}$ value controlled structural change in a series of rare earth complexes whith $p$-aminobenzoic acid, J. Mol. Struct. 702 (2004) 77-83.

[18] A.C. Gigante, D.J.C. Gomes, L.S. Lima, F.K. Caires, O. Treu-Filho, M. Ionashiro, Synthesis, thermal properties and spectrocopic study of solid mandelate of light trivalente lanthanides, Thermochim. Acta 536 (2012) 6-14.

[19] H.A. Flaschka, EDTA Titrations and Introduction to Theory and Practice, second ed., Pergamon Press, Oxford, 1964.

[20] M. Ionashiro, C.A.F. Gramer, J. Zuanon Netto, Titulação complexometrica de lantanideos e ítrio, Ecl. Quím. 8 (1983) 29-32.
[21] M.K. Rotich, B.D. Glass, M.E. Brown, Thermal studies on some substituted aminobenzoic acids, J. Therm. Anal. Calorim. 64 (2001) 681-688.

[22] M. Mukherjee, B. Bandyopadhyay, P. Biswas, T. Chakraborty, Amine inversion effects on the IR spectra of aniline in the gas phase and cold inert gas matrixes, Indian J. Phys. 86 (2012) 201-208.

[23] L.S. Lima, F.J. Caires, C.T. Carvalho, A.B. Siqueira, M. Ionashiro, Synthesis, characterization and thermal behaviour of solid-state compounds of light trivalente lanthanide succinates, Thermochim. Acta 501 (2010) 50-54.

[24] C.C.S.M. Brito, R.B.M. Oliveira, F.X. Campos, A.P. Cardoso, M.R.S. Soares, A.] Terezo, A.B. Siqueira, Characterization and thermal behaviour of tannic acid compounds with Zn(II) and Ni(II) in the solid state, Braz.J. Therm. Anal. 1 (2013) $8-14$.

[25] M. Samsonowicz, T. Hrynaszkiewicz, R. Swislocka, E. Regulska, W. Lewandowski, Experimental and theoretical IR, Raman, NMR, spectra of 2-, 3- and 4-aminobenzoic acids, J. Mol. Struct. 744-747 (2005) 345-352.

[26] R. Swislocka, M. Samsonowicz, E. Regulska, W. Lewandowski, Molecular structure of 4-aminobenzoic acid salts with alkali metals, J. Mol. Struct. 792-793 (2006) 227-238.

[27] G. Versanyi, Assignments for Vibrational Spectra of 700 Benzene Derivatives Akademiai Kiado, Budapest, Hungary, 1973.

[28] K. Nakamoto, Infrared and Raman Spectra of Inorganic and Coordination Compounds, fifth ed., Wiley, New York, NY, USA, 1997.

[29] G.B. Deacon, R.J. Phillips, Relationship between the carbon-oxygen stretching frequencies of carboxylate complexes and the type of carboxylate coordination, Coord. Chem. Rev. 33 (1980) 227-250.

[30] V.S. Sastri, J.C.G. Bünzli, V.R. Rao, G.V.S. Rayudu, J.R. Perumareddi, Modern Aspects of Rare Earths and Their Complexes, Elsevier, Amsterdam, 2003.

[31] K. Iftikhar, M. Sayeed, N. Ahmad, Lanthanoid shift reagents. Synthesis and spectral studies, Bull. Chem. Soc. Jpn. 55 (1982) 2258-2263. 